\title{
Antioksidan dan katarak
}

\author{
Mohammad Fachri Ibrahim ${ }^{1}$
}

\begin{abstract}
ABSTRAK
Katarak merupakan penyebab utama kebutaan di Indonesia maupun di dunia. Katarak adalah keadaan di mana terjadi kekeruhan terhadap lensa. Katarak dapat disebabkan oleh berbagai hal dan salah satunya adalah radikal bebas atau oksidan. Pada umumnya antioksidan diketahui dapat mencegah terjadinya katarak dengan cara menurunkan faktor risiko terbentuknya katarak. Hal ini dikarenakan antioksidan dapat menetralisir oksidan pada lensa. Antioksidan yang berkaitan dengan katarak antara lain vitamin C, vitamin E dan karotenoid. Antioksidan tersebut terbukti mempunyai hubungan dengan penurunan risiko terjadinya katarak pada beberapa studi. Tetapi, tidak semua penelitian mendapatkan hasil yang serupa. Maka dari itu diperlukan penelitian yang lebih terperinci mengenai manfaat antioksidan terhadap katarak.
\end{abstract}

\author{
${ }^{1}$ RSUD Cilincing, Jakarta, \\ Indonesia
}

\section{Korespondensi:}

Mohammad Fachri Ibrahim RSUD Cilincing, Jakarta, Indonesia Jalan Raya Kebantenan No.4, Semper Timur, Cilincing, Jakarta Utara, DKI Jakarta 14130 Phone: 081212614496

Email: ayfach.ibra@gmail.com

Kata kunci: katarak, vitamin C, vitamin E, karotenoid, antioksidan

\author{
J Biomedika Kesehat 2019;2(4):154- \\ 161 \\ DOI: 10.18051/JBiomedKes.2019. \\ v2.154-161 \\ pISSN: 2621-539X / eISSN: 2621-5470 \\ Artikel akses terbuka (open access) ini \\ didistribusikan di bawah lisensi Creative \\ Commons Attribution 4.0 International \\ (CC-BY 4.0)
}




\section{ABSTRACT}

\section{Antioxidants and cataracts}

Cataract is the main cause of blindness in Indonesia and also in the world. Cataract is a condition where the lense loses its transparency. There are many factors that can cause cataract, one of them is oxidant. In general, anioxidant are known for preventing cataracts by reducing cataracts risk farctors. Antioxidant is assumed to be able to prevent cataract by being neutralizer of oxidant. Antioxidant which relate with cataract are vitamin $\mathrm{C}$, vitamin $\mathrm{E}$, and carotenoid. In several studies, those antioxidants are proven to prevent cataract. But in some studies, show the opposite. Therefore more detail research about the function of oxidant against cataract is needed.

Keywords: cataracts, vitamin C, vitamin E, carotenoids, antioxidants

\section{PENDAHULUAN}

Data World Health Organization (WHO) menyatakan terdapat 36 juta orang diperkirakan buta pada tahun 2015 dengan 216.6 juta orang mempunyai masalah penglihatan yang berat. Pada survei kesehatan oleh Depkes RI tahun 1993-1996 didapatkan $1.5 \%$ atau lebih dari tiga juta penduduk Indonesia mengalami kebutaan. Penyebab masalah penglihatan dan kebutaan nomor satu di dunia adalah katarak, demikian juga di Indonesia, sebanyak 78\% kebutaan disebabkan oleh katarak, selanjutnya disebabkan oleh glaukoma, retinopati diabetikum, kekeruhan kornea, degenerasi macular, trakoma dan gangguan refraksi. ${ }^{(1)}$

Katarak merupakan perubahan kondisi penglihatan disebabkan oleh lensa yang mengeruh. Lensa merupakan salah satu media refraksi yang berbentuk bikonfeks dan berfungsi untuk memfokuskan cahaya yang masuk ke mata agar bisa sampai ke makula. Kekuatan lensa adalah 1020 dioptri tergantung kepada kekuatan akomodasi. (2)

Lensa terdiri dari $65 \%$ air, $35 \%$ protein dan sedikit mineral. Protein pembentuk lensa terdiri dari protein sitoplasma (larut air) dan protein sitoskeletal (tidak larut air). Sebesar $80 \%$ protein adalah protein sitoplasma yang terdiri dari kristalin yang memiliki sifat transparan. Pada proses degeneratif, protein sitoplasma akan teroksidasi sehingga menyebabkan kerusakan senyawa protein dan kekeruhan lensa sehingga menimbulkan katarak. Antioksidan dapat menghambat terjadinya proses oksidasi tersebut, sehingga diharapkan dapat mencegah terjadinya katarak. $^{(3)}$

Faktor risiko katarak dapat dibedakan menjadi tiga yaitu faktor individu, lingkungan dan faktor protektif. Faktor individu terdiri atas usia, jenis kelamin, ras, serta faktor genetik. Faktor lingkungan termasuk kebiasaan merokok, paparan sinar ultraviolet, status sosioekonomi, tingkat pendidikan, diabetes mellitus, hipertensi, penggunaan steroid dan obat-obat penyakit gout. Faktor protektif meliputi penggunaan aspirin dan terapi pengganti hormon pada wanita. ${ }^{(4)}$

Klasifikasi katarak dibagi menjadi dua yaitu klasifikasi berdasarkan usia dan klasifikasi berdasarkan letak katarak di dalam lensa. Klasifikasi katarak berdasarkan usia yaitu katarak kongenital, katarak juvenile dan katarak senilis. Katarak kongenital adalah katarak yang didapat sejak lahir di mana sepertiga dari seluruh kasus adalah diturunkan, sepertiga lagi akibat penyakit sistemik dan sisanya merupakan kasus idiopatik. Katarak senilis merupakan katarak yang disebabkan karena proses degeneratif dari lensa, dan katarak jenis ini mencakup 90\% dari semua kasus katarak. ${ }^{(4)}$

Manifestasi klinis yang sering muncul adalah keluhan penglihatan buram seperti ditutupi kabut, yang tidak dapat diperbaiki dengan penggunaan kacamata. Sebelum terjadi kekeruhan pada lensa, terlebih dahulu terjadi penebalan pada lensa. Pada keadaan ini, jatuhnya cahaya menjadi tertarik ke depan retina sehingga menyebabkan penglihatan dekat pada orang tua semakin baik tetapi penglihatan jauhnya semakin buruk atau bisa disebut sebagai second sight. ${ }^{(4)}$

Kerugian yang disebabkan oleh katarak adalah terganggunya aktivitas, dan pada kasus yang berat, katarak dapat menimbulkan ketergantungan terhadap orang lain, baik pada usia produktif maupun usia lanjut. Oleh karena itu, banyak penelitian telah dilakukan untuk mengetahui cara pencegahan katarak. Salah satunya adalah dengan menggunakan antioksidan guna mencegah terjadinya oksidasi pada lensa, di mana oksidasi merupakan faktor penting dalam mekanisme terjadinya katarak terutama pada katarak senilis. Sehingga dengan ditemukannya pencegahan 
katarak diharapkan dapat menekan angka kejadian katarak yang merupakan penyebab nomor satu kebutaan di Indonesia. Tinjauan artikel ini bertujuan untuk menelaah pengaruh antioksidan yaitu vitamin $C$, vitamin $E$ dan karotenoid terhadap pembentukan katarak.

\section{Metabolisme lensa}

Metabolisme lensa bertujuan untuk mendapatkan energi bagi lensa dan mempertahankan transparansi dari lensa. Lensa mendapatkan energi dari hasil metabolisme glukosa. Lensa mempertahankan transparansinya melalui metabolisme antioksidan, protein, dan mekanisme pengaturan keseimbangan cairan serta elektrolit. Berikut metabolisme zat-zat yang terdapat di dalam lensa:

\section{Metabolisme glukosa}

Glukosa di aqueous humor memasuki lensa melalui difusi sederhana dan difusi yang difasilitasi. Sekitar $90-95 \%$ glukosa yang masuk ke dalam lensa akan difosforilasi oleh enzim hexokinase menjadi glukosa-6-fosfat. Sekitar 3\% Glukosa-6-fosfat yang telah terbentuk di dalam lensa akan dimetabolisme melalui jalur glikolisis anaerob. Hal ini disebabkan karena ketiadaan pembuluh darah lensa sehingga kadar oksigen di dalam lensa menjadi sangat rendah. Jalur lain untuk metabolisme glukosa di dalam lensa adalah melalui jalur pentose fosfat. Sekitar 5\% dari keseluruhan glukosa di dalam lensa mengalami metabolisme melalui jalur ini. Jalur metabolisme terakhir yang dapat memetabolisme glukosa dalam lensa adalah jalur sorbitol. Jalur ini akan lebih aktif pada keadaan hiperglikemia. Pada jalur ini, glukosa akan diubah menjadi sorbitol oleh enzim aldose reductase yang berada pada epitel lensa. Kemudian, sorbitol akan dimetabolisme oleh enzim poliol dehydrogenase. Enzim poliol dehydrogenase tersebut mempunyai afinitas yang rendah sehingga dapat menyebabkan sorbitol terakumulasi sebelum dimetabolisme.

Penumpukan sorbitol di dalam lensa menyebabkan osmolaritas lensa meningkat sehingga menarik air. Penumpukan air di dalam lensa menyebabkan lensa menggembung sehingga dapat merusak sitoskeletal lensa dan mengakibatkan lensa menjadi keruh. Hal ini dapat menjelaskan mengapa penyakit Diabetes Melitus menjadi salah satu penyebab utama terjadinya katarak. ${ }^{(5)}$

\section{Metabolisme antioksidan}

Lensa mempunyai enzim-enzim yang berfungsi melindunginya dari zat-zat radikal bebas seperti glutation peroksidase, katalase, dan superoksida dismutase. Pada keadaan normal, terdapat zat-zat antioksidan di dalam lensa sehat seperti glutation, asam askorbat dan katalase. Glutation dapat dijumpai dalam jumlah besar terutama di lapisan epithelial. Glutation berfungsi untuk mempertahankan transparansi lensa dengan cara mencegah agregasi kristalin dan melindunginya dari kerusakan oksidatif. ${ }^{(6)}$

Mekanisme antioksidan pada lensa diawali dengan dismutase superoksida menjadi hidrogen peroksida oleh enzim superoksida dismutase. Selanjutnya, hidrogen peroksida akan diubah menjadi molekul air $\left(\mathrm{H}_{2} 0\right)$ dan oksigen $\left(\mathrm{O}_{2}\right)$ dengan bantuan enzim katalase. Selain itu, hidrogen peroksida akan menerima gugus hidrogen dari glutation tereduksi menjadi molekul air dengan bantuan enzim glutation peroksidase. Glutation yang telah teroksidasi akan menjadi tidak aktif. NADPH (Nicotinamide Adenine Dinucleotide Phosphate) yang berasal dari jalur pentose akan mengubahnya kembali menjadi glutation tereduksi dengan bantuan enzim glutation reduktase. ${ }^{(6,7)}$

\section{Metabolisme protein}

Protein lensa dapat dimetabolisme. Protein lensa akan diubah oleh enzim endopeptidase menjadi peptida yang akan dirombak menjadi asam amino oleh enzim eksopeptidase. Calpain adalah contoh dari enzim endopeptidase yang terdapat pada lensa. Sedangkan, calpastatin yang merupakan inhibitor calpain terdapat pada lensa dengan jumlah yang lebih banyak dari calpain. Hal ini menyebabkan protein lensa dapat stabil dalam jangka waktu yang panjang. ${ }^{(8)}$

\section{Mekanisme pengaturan keseimbangan asam dan basa}

Keseimbangan elektrolit merupakan salah satu hal yang penting dalam mempertahankan transparansi lensa. Transparansi lensa sangat bergantung pada komponen struktural dan makromolekular. Hidrasi lensa juga dapat 


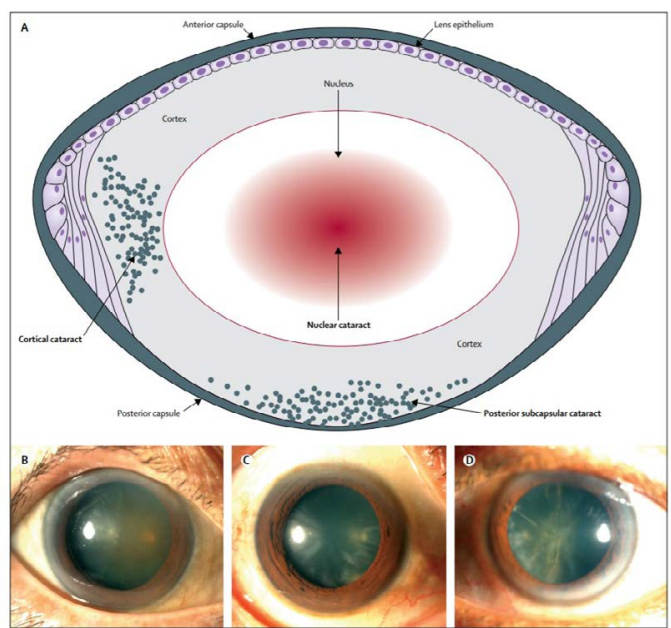

Gambar 1. Jenis-jenis katarak: (a) Lokasi terjadinya katarak pada lensa; (b) Penampakan katarak nuklearis; (c) Penampakan katarak kortikalis; (d) Penampakan katarak subkapsularis posterior. ${ }^{(10)}$

menyebabkan kekeruhan pada lensa. Lensa mempunyai kadar kalium dan asam amino yang lebih tinggi dari pada vitreus dan aqueous humor dan mempunyai kadar natrium yang lebih rendah dari sekitarnya. Keseimbangan kalium dan natrium diatur oleh kombinasi permeabilitas lensa dan kerja pompa natrium- kalium. Natrium akan masuk ke dalam lensa melalui bagian posterior lensa secara difusi dan keluar dari lensa melalui bagian anterior lensa dengan menggunakan pompa natrium-kalium. Pada saat yang bersamaan, kalium dan asam amino juga secara aktif masuk dari bagian anterior lensa dan selanjutnya keluar melalui bagian posterior lensa dengan cara difusi. (8)

\section{Patogenesis katarak}

Pada katarak senilis, protein pada lensa yang tadinya berbentuk larut, akan membentuk suatu agregasi protein menjadi suatu agregat yang bermolekul besar. Posttranslational modification associated disulfide bond formation dan glikasi non-enzimatik merupakan faktor utama yang berperan dalam agregasi protein di dalam lensa. ${ }^{(3)}$

Pada keadaan normal, terdapat zat-zat antioksidan di dalam lensa sehat seperti glutation, asam askorbat dan cathalase. (3) Oksidan atau radikal bebas dapat menyebabkan kerusakan pada lensa. Contoh zat-zat radikal bebas yang terdapat pada lensa adalah hydrogen peroksida $\left(\mathrm{H}_{2} \mathrm{O}_{2}\right)$, anion superoksida $\left(\mathrm{O} 2^{-}\right)$, radikal peoksil $\left(\mathrm{ROO}^{+}\right)$, radikal lipid peroksil $(\mathrm{LOOH})$, Oksigen $(\mathrm{O} 2)$, dan hidroksil $\left(\mathrm{OH}^{+}\right) \cdot \mathrm{H}_{2} \mathrm{O}_{2}$ merupakan oksidan utama dalam patogenesis terjadinya katarak. Pada keadaan normal $\mathrm{H}_{2} \mathrm{O}_{2}$ akan dieliminasi oleh Reduced Glutathion (GSH) melalui aktivitas dari enzim glutation peroksidase dan katalase. GSH dapat bereaksi dengan oksidan-oksidan seperti peroksida, superoksida, dan hydroxyl radical yang dikelompokan menjadi Reactive Oxygen Species atau biasa disingkat ROS. GSH yang bereaksi dengan ROS akan mengubah bentuk GSH menjadi bentuk yang teroksidasi yaitu GSSG. Karena perubahan GSH yang merupakan antioksidan dari $\mathrm{H}_{2} \mathrm{O}_{2}$ tersebut menyebabkan jumlah $\mathrm{H}_{2} \mathrm{O}_{2}$ meningkat di dalam lensa. ${ }^{(2,9)}$ Zat-zat radikal bebas ini akan menyebabkan perolsodasi lipid membran membentuk malondialdehida yang akan membentuk ikatan silang antara protein dan lipid. Hal tersebut dapat menyebabkan agregasi kristalin sehingga lensa menjadi keruh, serta inaktivasi enzim-enzim yang berperan dalam mekanisme antioksidan seperti katalase dan glutation reductase. Keadaan ini dapat mengakibatkan kematian sel epitel dan hilangnya transparansi dari lensa. ${ }^{(3)}$

Selain glutation, antioksidan yang sangat berpengaruh dalam melawan radikal bebas di dalam lensa adalah asam askorbat atau vitamin C. Vitamin C bertindak sebagai antioksidan fisiologis pada level tekanan oksigen yang rendah, berfungsi sebagai pelindung dari penyakit dan proses degenerasi yang disebabkan oleh stres oksidatif. Vitamin $\mathrm{C}$ mempunyai hasil paling baik secara in vivo dalam hal sebagai antioksidan dibandingkan antioksidan lain. Vitamin $\mathrm{C}$ juga mempunyai peran biologis yang penting terhadap lensa di mana konsentrasi vitamin $\mathrm{C}$ di dalam

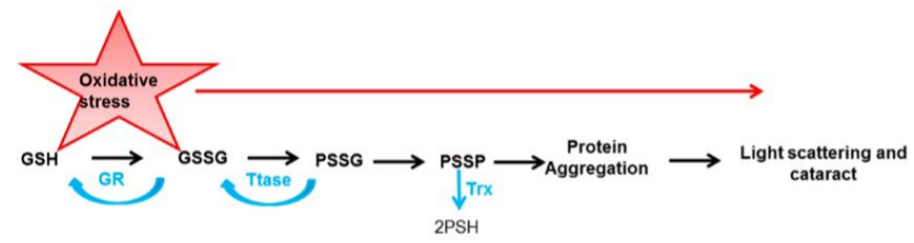

Gambar 2. Regulasi Radical Oxygen Species sebagai radikal bebas pada lensa. ${ }^{(9)}$ 
lensa ditemukan sekitar 20 sampai 30 lipat lebih tinggi dibandingkan konsentrasinya di dalam plasma, bahkan lebih tinggi dari kadar vitamin $\mathrm{C}$ di dalam vitreous. Pada penelitian terakhir di India ditemukan kadar vitamin $\mathrm{C}$ pada lensa normal jauh lebih tinggi dari kadar vitamin $\mathrm{C}$ pada lensa dengan katarak matur. ${ }^{(11)}$

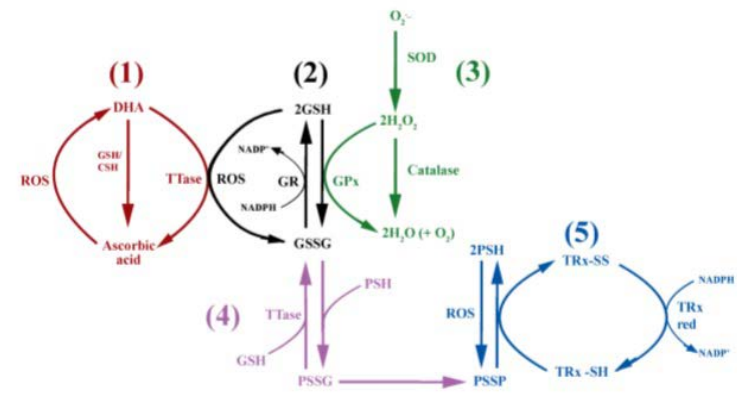

Gambar 3. Peran Oxidative Stress dalam pembentukan katarak. ${ }^{(2)}$

\section{Hubungan antara antioksidan dan katarak}

Pada 10 tahun terakhir telah dilakukan banyak penelitian mengenai hubungan antara antioksidan dan katarak khususnya katarak senilis. Pada penelitian yang dilakukan oleh Cui $\mathrm{YH}$, ditemukan adanya hubungan terbalik antara kadar antioksidan di dalam darah dengan risiko terjadinya katarak. ${ }^{(12)}$

Antioksidan yang dipilih oleh penulis adalah vitamin $\mathrm{C}$, Vitamin $\mathrm{E}$ dan karotenoid. Antioksidan tersebut merupakan antioksidan yang berperan dalam pencegahan katarak yang sesuai dengan patogenesis terbentuknya katarak dan bisa didapatkan melalui makanan maupun suplemen sedangkan glutation merupakan antioksidan esensial yang sudah ada di dalam lensa.

\section{Vitamin C}

Vitamin $\mathrm{C}$ atau asam askorbat merupakan salah satu vitamin larut air yang terkadung dalam beberapa jenis makanan terutama buah-buahan. Vitamin $\mathrm{C}$ di dalam tubuh berperan sebagai antioksidan yang berfungsi untuk melindungi sel-sel dari kerusakan yang disebabkan oleh radikal bebas. Vitamin $\mathrm{C}$ juga merupakan salah satu antioksidan yang terkandung di dalam lensa. Mekanisme terbentuknya katarak khususnya katarak senilis, dapat disebabkan karena stres oksidatif oleh zat-zat oksidan seperti peroksida, superoksida, dan oksidan-oksidan lain yang termasuk reactive oxygen species (ROS). ${ }^{(13)}$ Kisic $\mathrm{B}$, et al, pada penelitiannya menunjukkan adanya perbedaan yang signifikan antara jumlah oksidan di dalam lensa dengan katarak matur dibandingkan dengan lensa normal. ${ }^{(14)}$

Vitamin Catau asamaskorbatjuga berperan penting dalam menurunkan angka kejadian katarak yang ditunjukkan dalam penelitian oleh Atti $\mathrm{S}$, et $a l .{ }^{(15)}$ Dalam penelitiannya, dilakukan studi case control terhadap 100 pasien dengan katarak senilis serta mengukur kadar vitamin $\mathrm{C}$ dalam serum pasien-pasien tersebut. Hasilnya didapatkan rendahnya kadar vitamin $\mathrm{C}$ dalam serum pasien dengan katarak senilis jika dibandingkan dengan pasien kontrolnya. Hasil penelitian ini sejalan dengan penelitian yang dilakukan oleh Pastorvalero $\mathrm{M}$ di mana dalam penelitiannya ditemukan hubungan yang signifikan antara konsumsi vitamin $\mathrm{C}$ dengan dosis $>107 \mathrm{mg}$ per hari dengan penurunan prevalensi kejadian katarak senilis. ${ }^{(11)}$ Hal ini didukung juga oleh studi yang dilakukan oleh Breakhuis AJ et al, di mana dalam tinjauan artikel yang membahas tentang strategi nutrisi untuk mencegah katarak, disebutkan bahwa konsumsi vitamin $\mathrm{C}$ dalam dosis kecil $(<100 \mathrm{mg}$ per hari) mempunyai hubungan terhadap penurunan risiko katarak senilis, dan konsumsi vitamin $\mathrm{C}$ dalam dosis sedang (250mg per hari) dapat menurunkan tanda dan gejala katarak setelah dilakukan percobaan pada pasien selama 3 bulan. (2) Sedangkan konsumsi vitamin C dalam dosis tinggi (1000mg per hari) akan meningkatkan risiko terjadinya katarak sebesar $21 \%$. Beberapa penelitian menyatakan vitamin $\mathrm{C}$ dapat berperan sebagai antioksidan maupun prooksidan. Hal ini tergantung dari kadar vitamin $\mathrm{C}$, oksigen dan ion Fe. ${ }^{(14)}$

Vitamin $\mathrm{C}$ bisa menjadi oksidan bila teroksidasi oleh ion $\mathrm{Fe}$ sehingga diperkirakan dapat meningkatkan risiko terjadinya katarak. Diketahui bahwa terdapat ion Fe dalam konsentrasi yang kecil (micromolar) di dalam lensa. Dengan adanya ion $\mathrm{Fe}$ serta oksigen di dalam lensa akan mengakibatkan vitamin $\mathrm{C}$ teroksidasi menjadi dehidroaskorbat yang nantinya akan menghasilkan hydrogen peroksida dan ion $\mathrm{Fe}$ akan tereduksi. Hydrogen peroksida yang dihasilkan tersebut dapat bereaksi dengan ion logam yang telah tereduksi dan membentuk hydroxyl dan zat-zat oksidan lainnya yang termasuk dalam reactive 
oxygen species (ROS). ${ }^{(14,15)}$ Hal ini dibuktikan oleh Kisic B, et al, dalam penelitiannya yang menunjukkan bahwa terdapat hubungan antara vitamin $\mathrm{C}$ dan ferric reducing ability pada lensa dengan katarak matur. ${ }^{(14)}$

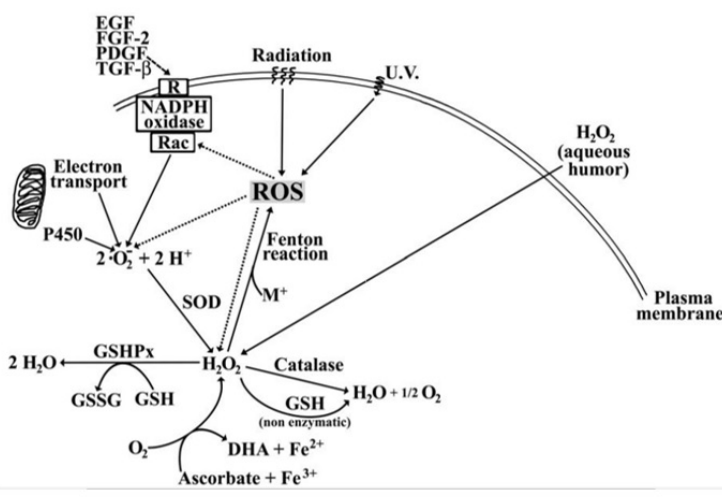

Gambar 4. Proses oksigen, vitamin $\mathrm{C}$ dan ion Fe menjadi hydrogen peroksida (radikal bebas). ${ }^{(16)}$

Tetapitidaksemuapenelitianmenunjukkan hasil yang sama dengan penelitian-penelitian di atas. Pada penelitian yang dilakukan oleh Mathew MC tidak ditemukan adanya hubungan antara konsumsi vitamin $\mathrm{C}$, baik tunggal maupun dikombinasikan bersama vitamin $\mathrm{E}$, dengan risiko terjadinya katarak. ${ }^{(13)}$ Di dalam tinjauan yang dilakukan oleh Thiagarajan $\mathrm{R}$, dinyatakan bahwa efesiensi vitamin $\mathrm{C}$ dalam mencegah segala jenis katarak masih belum jelas. Perlu ditekankan bahwa vitamin $\mathrm{C}$ juga dapat menghasilkan zat-zat oksidan yang berbahaya bagi lensa. Pemberian suplemen vitamin $\mathrm{C}$ dosis tinggi meningkatkan angka kejadian katarak senilis pada wanita. ${ }^{(17)}$ Selain itu, suatu studi kohort di Amerika Serikat yang dilakukan oleh Christen WG terhadap 11.545 laki-laki yang berumur lebih dari 50 tahun dengan atau tanpa katarak selama 8 tahun, didapatkan tidak ada efek yang bermakna antara konsumsi vitamin C $500 \mathrm{mg}$ per hari dengan risiko terjadinya katarak. ${ }^{(18)}$ Penelitian di tempat lain yang dilakukan oleh Rautiainen S, menggunakan metode studi kohort selama 8 tahun pada wanita di Swedia, menyatakan bahwa konsumsi vitamin $\mathrm{C}$ sebagai nutrisi tambahan berhubungan dengan peningkatan risiko katarak. ${ }^{(19)}$

\section{Vitamin $E$}

Vitamin E adalah salah satu nutrisi esensial, larut dalam lemak, yang berfungsi sebagai salah satu antioksidan. Vitamin E bisa ditemukan di sejumlah makanan contohnya kacang almond, minyak biji gandum, bayam, alpukat, brokoli, dan mangga. Terdapat delapan bentuk vitamin $\mathrm{E}$ yaitu alpha-, beta-, gamma-, delta-tocopherol dan alpha-, beta-, gamma-, delta-tocotrienol. Vitamin E bentuk alpha-tocopherol merupakan satusatunya bentuk yang dapat memenuhi kebutuhan manusia. Penyerapan vitamin E bergantung pada hati (hepar). Hati hanya akan resekresi alphatocopherol melalui hepatic alpha-tocopherol transfer protein, namun untuk bentuk vitamin E lainnya akan dimetabolisme dan dieskresi. Pada lensa, vitamin E dapat menginhibisi peroksidasi lipid dan membantu mempertahankan kontinuitas serta fungsi dari membran tersebut. ${ }^{(20)}$ Beberapa studi menunjukkan bahwa vitamin $\mathrm{E}$ dapat menunda galactose dan aminothizole-induced cataract pada mata kelinci. Vitamin E sama seperti vitamin $\mathrm{C}$ juga dianggap sebagai pencegah utama terhadap katarak senilis dan irradiation-induced cataract. ${ }^{(17)}$

Beberapa penelitian telah membuktikan bahwa asupan antioksidan dapatmenurunkanfaktor risiko terjadinya katarak. Zhang Y et al, melakukan tinjauan artikel-artikel yang berkaitan dengan vitamin E dan katarak senilis, dan didapatkan hasil bahwa konsumsi suplemen vitamin E mempunyai hubungan dengan penurunan faktor risiko katarak senilis. ${ }^{(21)}$ Pada studi kohort yang dilakukan oleh Christen WG, et al, ditemukan bahwa adanya hubungan konsumsi vitamin $\mathrm{E}$ dalam jangka panjang dengan terjadinya katarak senilis. ${ }^{(22)}$ Hasil tersebut sesuai dengan penelitian yang dilakukan oleh Pastor-valero M yang menggunakan Food Frequency Questionnaire (FFQ) sebagai alat untuk menilai asupan nutrisi, di mana didapatkan hasil bahwa konsumsi vitamin E sebanyak $8 \mathrm{mg}$ tiap hari secara rutin mempunyai hubungan yang signifikan terhadap penurunan prevalensi kejadian katarak senilis. ${ }^{(11)}$

Tetapi tidak semua penelitian mendapatkan hasil serupa, contohnya pada penelitian yang dilakukan oleh Gritz DC di mana tidak ditemukan adanya efek dari pemberian suplemen vitamin $\mathrm{E}$ terhadap progresi katarak. ${ }^{(23)}$ Pada penelitiannya yang lain, Christen WG menunjukkan bahwa tidak ditemukan adanya efek pemberian vitamin E dengan dosis 400 IU per hari terhadap risiko terjadinya katarak. ${ }^{(18)}$ 


\section{Karotenoid}

Karotenoid adalah senyawa poliena isoprenoid yang merupakan pigmen alami pada tumbuhan atau hewan berwarna kuning oranye. Terdapat 2 jenis karotenoid yaitu karoten dan xantofil. Karoten adalah hidrokarbon atau turunannya yang terdiri dari beberapa unit isoprene, contohnya adalah alpha-karoten, betakaroten, gamma-karoten dan likopen. Xantofil adalah karotenoid yang mengandung gugus hidroxil, contohnya lutein, zeaxantin,violaxantin. Di dalam tubuh, karotenoid berperan sebagai salah satu oksidan seperti halnya vitamin $\mathrm{C}$ dan vitamin E. Pada studi terkini, karotenoid dijadikan salah satu antioksidan yang dapat mencegah terjadinya katarak, walaupun masih sedikit yang membahas hal tersebut. Menurut studi kepustakaan yang dilakukan oleh Manayi A, mekanisme lutein dalam mencegah terjadinya katarak masih belum dapat dijelaskan secara mendetail, namun beberapa studi menunjukkan bahwa ada hubungan yang signifikan antara karotenoid dengan penurunan risiko katarak. ${ }^{(24)}$ Karotenoid terutama lutein, juga disebutkan dapat menginhibisi reaksi dari sinar ultraviolet (UV) terhadap lensa sehingga dapat mencegah terjadinya ultraviolet-induced cataractogenesis. Salah satunya adalah studi kohort yang dilakukan oleh Brown L terhadap laki-laki berumur 45-75 tahun selama 8 tahun didapatkan adanya hubungan yang signifikan antara konsumsi karotenoid dan penurunan risiko terjadinya katarak. ${ }^{(25)}$ Hasil yang sama juga didapatkan oleh Christen WG. ${ }^{(22)}$

\section{KESIMPULAN}

Berdasarkan pembahasan di atas dapat disimpulkan bahwa vitamin $\mathrm{C}$, vitamin $\mathrm{E}$, dan karotenoid tidak selalu bisa mencegah terjadinya katarak. Vitamin $\mathrm{C}$ dapat menjadi antioksidan dan juga dapat menjadi prooksidan yang dapat meningkatkan risiko terjadinya katarak. Hal ini tergantung dari dosis dari vitamin $\mathrm{C}$ yang dikonsumsi. Vitamin $\mathrm{C}$ dengan dosis yang tidak berlebihan dapat menjadi antioksidan yang dapat melawan radikal bebas yang terdapat pada lensa. Vitamin E juga merupakan antioksidan yang dapat melawan radikal bebas pada lensa dan dalam beberapa studi dilaporkan dapat menurunkan risiko terjadinya katarak. Meskipun ada beberapa studi yang mendapatkan hasil bahwa penggunaan vitamin E tidak berhubungan dengan penurunan risiko katarak. Tidak seperti vitamin $\mathrm{C}$, penggunaan vitamin $\mathrm{E}$ dosis tinggi secara rutin tidak dapat meningkatkan risiko terjadinya katarak, tetapi tidak juga dapat menurunkan risiko katarak. Karotenoid dilaporkan dapat menurunkan risiko katarak dengan menjadi antioksidan yang berfungsi melawan radikal bebas dan karotenoid juga dapat menghambat reaksi yang disebabkan oleh sinar UV, sehingga zat karotenoid dapat mencegah terjadinya ultraviolet-induced cataractogenesis. Jumlah penelitian karotenoid sebagai pencegah terjadinya katarak masih terbatas, sehingga dibutuhkan penelitian atau studi lebih lanjut terhadap hubungan antara karotenoid dan katarak.

\section{KONFLIK KEPENTINGAN}

Penulis menyatakan tidak terdapat konflik kepentingan

\section{KONTRIBUTOR}

Mohammad Fachri Ibrahim

\section{REFERENSI}

1. InfoDATIN: Situasi Gangguan Penglihatan Dan Kebutaan. Available at: www.depkes.go.id , download , infodatin-penglihatan Accessed on 2019 August

2. Braakhuis AJ, Donaldson CI, Lim JC, et al. Nutritional Strategies To Prevent Lens Cataract: Current Status And Future Strategies. Nutrients 2019;11(5):1-20. doi: 10.3390/nu11051186.

3. Kaur A, Gupta V, Christoper AF, et al. Nutraceutical In Prevention Of Cataract, An Evidence Based Approach. Saudi J Opthalmol 2017:31(1):30-7. doi: 10.1016/j.sjopt.2016.12.001

4. Riordan-Eva P, Whitcher JP. Vaughan Dan Aspbury Oftalmologi Umum. 17 ed. Pendit BU, translator. Jakarta: EGC; 2009. 170-4

5. Pintor J. Sugar Crystalline Lens And The Development Of Cataract. Biochem Pharmacol 2012;1(4):1-3. DOI: 10.4172/2167$0501.1000 \mathrm{e} 119$.

6. Christen WG, Glynn RJ, Gaziano $M$, et al. Age-Related Cataract In Men In Selenium And Vitamin E Cancer Prevention Trial Eye Endpoints Study: a randomized clinical trial. JAMA Opthalmol 2015;133(1):17-24. doi: 10.1001/ jamaophthalmol.2014.3478.

7. Chang D, Zhang $X$, Rong $S$, Sha $Q$, et al. Serum Antioxidative Enzymes Levels And Oxidative Stress Products In Age-Related Cataract Patients. Oxidative Medicine and Cellular Longevity 2013;2013:1-7. http://dx.doi. org/10.1155/2013/587826.

8. Hetjmancik JF, Raizuddin SA, McGreal R, et al. Lens Biology And Biochemistry. Prog Mol Biol Transl Sci 2015;134:169-201. doi: 10.1016/ 
bs.pmbts.2015.04.007.

9. Umapathy A. Glutathione Metabolism And Transport Pathways In The Anterior Rat Eye: Is The Lens Is A Reservoir Of Glutathione. [Dissertation] Auckland. University Of Auckland; 2015.

10. Liu YC, Wilkins M, Kim T, et al. Cataract. Lancet 2017;390(10094):600-12. doi: 10.1016/S01406736(17)30544-5.

11. Pastor-Valero M. Fruit And Vegetable Intake And Vitamins C And E Are Associated With A Reduced Prevalence Of Cataract In A Spanish Mediterranean Population. BMC Ophtalmol 2013;13(52):1-15. doi: 10.1186/1471-2415-13-52

12. Cui YH, Jing CX, Pan HW. Association Of Blood Antioxidants And Vitamins With Risk Of Age-Related Cataract: A Meta-Analysis Of Observational Studies. Am J Clin Nutr 2013;98(3):778-86. doi: 10.3945/ajen.112.053835

13. Mathew MC, Ervin AM, Tao J, et al. Antioxidant Vitamin Supplementation For Preventing And Slowing The Progression OfAge-Related Cataract. Cochrane Database Syst Rev 2012;13(6):1-25. doi:10.1002/14651858.CD004567.pub2.

14. Kisic B, Miric D, Zoric L, et al. Antioxidant Capacity Of Lenses With Age-Related Cataract. Oxidative Medicine and Cellular Longevity 2012; 2012:1-8. doi:10.1155/2012/467130.

15. Angirekula S, Atti L, Atti S. Estimation Of Serum Ascorbic Acid (Vitamin C) In The Age Related (Senile) Cataract: A Case Control Study. Ann Clin Lab Res 2018;6(1):1-5. DOI: 10.21767/23865180.1000217.

16. Berthoud MV, Beyer EC. Oxidative Stress, Lens Gap Junction And Cataract. Mary Ann Liebert, Inn 2009;11(2):339-53. doi: 10.1089/ars.2008.2119.

17. Thiagarajan R, Manikandan R. Antioxidant And Cataract. Informa Healthcare 2013;47(5):337-45. doi: 10.3109/10715762.2013.777155.

18. Christen WG, Glynn RJ, Sesso HD, et al. AgeRelated Cataract In A Randomized Trial Of Vitamin E And C In Men. Arch Ophthalmol 2010;128(11):1397-405. doi: 10.1001 archophthalmol.2010.266.

19. Rautiainen S, Lindblad BE, Morgenstem R, et al. Total Antioxidant Capacity Of The Diet And Risk Of Age-Related Cataract: A PopulationBased Prospective Cohort Of Women. JAMA Opthalmol 2014;132(3);247-52. doi: 10.1001/ jamaophthalmol.2013.6241.

20. National Institute Of Health: Vitamin E. Available at : https://ods.od.nih.gov/factsheets/VitaminEHealthProfessional/\#en6. Accessed on 2019 August.

21. Zhang Y, Jiang W, Xie Z, Wu W, Zhang D. Vitamin E And Risk Of Age-Related Cataract: a metaanalysis. Public Health Nutr. 2015;18(15):280414. doi: $10.1017 / \mathrm{S} 1368980014003115$.

22. Christen WG, Glynn RJ, Gaziano M, et al. Age-Related Cataract In Men In Selenium And Vitamin E Cancer Prevention Trial Eye Endpoints Study: a randomized clinical trial. JAMA Opthalmol 2015;133(1):17-24. doi: 10.1001/ jamaophthalmol.2014.3478.

23. Gritz DC, Srinivasan M, Smith SD, et al. The Antioxidants In Prevention Of Cataracts Study: Effects Of Antioxidant Supplements On Cataract Progression In South India. $\mathrm{Br} \mathrm{J}$ Opthalmol 2006;90(7):847-51. DOI: 10.1136/ bjo.2005.088104

24. Manayi A, Abdollahi M, Thiagarajan R,
Nabavi SF, Hebtemariam S, Daglia $m$, et al. Lutein And Cataract: From Bench To Bedside. Crit Rev Biotechnol 2016;36(5):829-39. doi: 10.3109/07388551.2015.1049510.

25. Brown L, RimmEB, Sedoon JM, Giovannucci EL, Chasan-Taber L, Spiegelman D, et al. A Prospective Study Of Carotenoid Intake And Risk Of Cataract Extraction In US Men. Am J Clin Nutr 1999;70(4):517-24. DOI:10.1093/ajen/70.4.517 